\title{
LONG-TERM AND SHORT-TERM EQUITY MARKET PRICE INTERACTIONS BETWEEN AUSTRALIA AND THE CHINESE STATES ${ }^{\#}$
}

\author{
EDUARDO D. ROCA \\ Griffith University \\ MARK BRIMBLE \\ Griffith University
}

This study investigates the extent and manner of long-term and short-term price interaction between the equity market of Australia and those of China, Hong Kong, Singapore and Taiwan taking into account the effect of the Asian financial crisis. It uses cointegration and generalised forecast variance and impulse response analyses. The study finds no long-term price relationship between the equity markets of Australia and the Chinese states. The short-term evidence indicates that Australia was only significantly interdependent with Hong Kong during the preAsian crisis period and with Hong Kong and Singapore during the post-crisis period. Australia and these markets react to a shock from each other immediately during the first day and complete this reaction by day two. These findings are useful for investors and policy makers, especially in light of the economic importance of these nations and China's recent admittance to the World Trade Organisation.

Keywords: equity market interaction, cointegration, generalised variance decomposition and impulse response analysis, Chinese states equity markets

Correspondence: Dr. Eduardo D. Roca, Department of Accounting, Finance and Economics, Griffith University, Nathan, Queensland, Australia 4111. Email: E.Roca@griffith.edu.au, telephone: +61 73875 7583, fax: +61 738757760 .

\# The authors acknowledge the financial support provided by the Department of Accounting, Finance and Economics, Griffith University in the conduct of this study. 


\section{INTRODUCTION}

This paper examines the extent and structure of price interdependence between the equity market of Australia and those of the Chinese States - Hong Kong, Singapore, Taiwan and China using an Australian perspective. The issue of financial market interdependence or integration is one whose importance is well-recognised, from the point of view of portfolio diversification and macroeconomics of open economies based on the Mundell-Fleming theories. However, inspite of the great build up of the financial market integration literature over the last five years, the issue as to whether or not financial markets are integrated or interdependent is far from being settled. The results of existing studies vary depending on the framework, methodology, data and time period used. Furthermore, the bulk of these studies focus on the developed markets (see Masih and Masih 2001). This study seeks to make a contribution to this literature in the following ways.

First, as far as the present writers are aware of, there is no study that focuses primarily on the equity market linkages between Australia and the Chinese states using an Australian perspective. There are a number of studies on Australia's equity market linkages but none of these studies

deal mainly with the Chinese states. For instance, McNelis (1993) focused on the US, Japan and Germany; Allen and MacDonald (1995) on a number of developed and Asia-Pacific markets and Roca and Selvanathan (2001) on the Chinese states but excluding China.

Second, the present study takes into account the effect of the Asian financial crisis in its analyes while previous studies have mainly dealt with the period before the Asian crisis. Allen and 
MacDonald (1993) covered the period from 1970 to 1992; Roca and Selvanathan (2001), the period 1975 to 1995 and McNelis (1993), the period 1983 to 1992.

Third, this study uses the techniques of forecast variance and decomposition analyses based on the generalised approach recently developed by Pesaran and Shin (1998) to investigate the shortterm interaction between the equity markets of Australia and the Chinese states. Prior to the formulation of the generalised approach, the Cholesky-decomposition was the main method used. The latter method, however, suffers from the problem of its results being sensitive to the ordering of variables in the vector autoregression (VAR). The generalised method overcomes this problem and it was in fact for this purpose that this new method was developed (Dekker et al 2001). Previous studies on Australia’s equity market linkages, such as McNelis (1993) and Roca and Selvanathan (2001) utilised the Cholesky decomposition approach. Thus, the present study is expected to provide more robust results.

The group of Australia and the Chinese states is interesting and a logical choice as a basis for studying equity market linkages. First, they represent vibrant and fast-growing economies in the most dynamic part of the world - the Asia Pacific. Despite being in the region where the Asian financial crisis occurred, their GDPs still grew much faster than that of any of the world's three largest economies -US, Japan and Germany, during the period 1990-2000 (see Table 1, column 3). Furthermore, the Chinese states are among the top countries in the world in terms of international reserves. As can be seen in Table 1 (column 4), in this aspect, they were even ahead of Germany during the year 1999. Also of importance is that Australia was hardly affected by the Asian crisis and although the Chinese states, with the exception of China, were, 
they were the least impacted compared to other Asian countries and were the ones to make the quickest recovery (Roger, 2001).

\section{Insert Table 1 here}

Second, the Chinese states, as a group, are a very significant trading partner of Australia, representing Australia's third largest trading partner behind the US and Japan (Department of Foreign Affairs and Trade, 2000). As can be seen in Table 2 (column 5), the Chinese states as a bloc accounted for a proportion of Australia's total trade in 1998, which was just a little below that of the US. It has been found that countries with close economic ties tend to have more integrated or interdependent equity markets, such as for instance, in the case of the US and Canada (Jorion and Schwartz, 1986), and Malaysia and Singapore (Cheung and Ho, 1991). Does this therefore mean that the equity markets of Australia and the Chinese states are integrated or interdependent? Australia, however, is hardly a significant trading partner of each of Chinese states. As can be seen in column 4 of Table 2, Australia was only responsible for $1.6 \%$ of the Chinese states’ combined total trade during the years 1993 and 1998. Hence, Australia is more economically dependent on the Chinese states rather than vice versa, and if indeed Australia is interdependent with the Chinese states, the economic fundamentals of the Chinese states could be expected to drive prices in Australia's stock market but not vice versa. For this reason, it would be more interesting to analyse the interaction between Australia and the Chinese states from Australia's perspective as the results of such study would be more useful to Australian investors and policymakers than to those of the Chinese states. 
Insert Table 2 here

Third, Australia and the Chinese states have very active equity markets that have grown tremendously since the beginning of the 1990s. As shown in Table 3, the market capitalisation (columns 2 and 3) of each of these markets has grown hugely the during the period 1990 to 1999 in such a way that the value of their stock markets has become bigger than their respective GDPs during the year 1999 (see columns 4 and 5). In terms of capitalisation, in 1999, Hong Kong has the largest market and Singapore, the smallest. The Taiwanese stock market is characterised by very high turnover, which is many times higher than that of Australia, Hong Kong and Singapore (see columns 6 and 7). Thus, given these characteristics, the equity markets of Australia and the Chinese states provide a very good laboratory for the testing of financial integration or interdependence.

Insert Table 3 here

Fourth, the level of development and financial openness of these markets differ considerably. The financial markets of Australia, Hong Kong and Singapore are well developed and open, while those of Taiwan and China are relatively underdeveloped and restricted. However, the advent of the Asian crisis and the subsequent intervention of the International Monetary Fund provided the impetus for the revival of financial reforms in the Chinese states. These reforms, which include the liberalization of capital flows, had previously stalled due to political factors. As a result of this new environment, the financial markets of China and Taiwan have become more open since the Asian crisis. The differences in financial openness among these markets 
make it difficult to infer the price interaction between them without resorting to a rigorous empirical analysis. A study such as the present one is therefore called for.

Fifth, there has been a high level of interest on the financial markets of the Chinese states by Australian investors in search of portfolio diversification opportunities overseas. This has intensified with China joining the World Trade Organisation (WTO) in 2001 and will strengthen as deregulation and liberalisation of markets gathers pace over the coming years. Thus, knowledge of the linkages among these markets is of practical usefulness.

The remainder of the study is structured as follows. The next section (Section 2) discusses the hypotheses, method and data. Section 3 presents the empirical results, while Section 4 gives the conclusion of the study.

\section{HYPOTHESES, METHODOLOGY AND DATA}

Since the stock market is supposed to mirror the economy (Dickinson, 2000), and given the high level of economic dependence of Australia on the Chinese states rather than vice versa, it could be expected that the Australian equity market will be significantly influenced by those of the Chinese states, particularly Hong Kong and Singapore. However, since Australia’s stock market is one that is relatively large compared to those of China and Singapore, it may be expected to also exert some influence on the Chinese states, particularly on China and Singapore. Furthermore, as Australia and the Chinese states lie within the same time zone, it is expected that each market will be able to respond to a shock from another market immediately within a day, 
and that the response will be completed within a period of two days, as has been found in previous studies (see, Eun and Shim, 1989). Due to the increase in openness of the Chinese states' financial markets after the Asian crisis, as discussed earlier, it could be expected that Australia’s interdependence with the Chinese states would have intensified after the Asian crisis.

These expectations will be examined with the use of the recently developed techniques of cointegration and its associated error correction modelling (ECM), and innovation accounting forecast variance decomposition and impulse response analyses, within a vector autoregression (VAR) context. These methodologies are now well established in the literature; hence, in order to save space, we no longer provide a detailed discussion of these methods. The reader who is interested in these details is referred to the relevant articles cited in this paper.

Cointegration, based on the Johansen-Juselius (1990) methodology is utilised in the examination of the long-term linkages between the equity markets of Australia and the Chinese states. It is well known that this technique avoids the loss of valuable long-term information as it allows the analyses to be done without the need for differencing when the variables are non-stationary. A finding of cointegration implies the existence of a long-term steady relationship. Innovation accounting, on the other hand, is used in the analyses of the structure of the short-term interactions between Australia’s and the Chinese states’ equity markets. The forecast variance analyses give the proportion of the forecast variance of each market accounted for by a shock coming from the different markets including from itself. Thus, these can indicate the degree of influence of one market on another. The impulse response analyses trace the response over time of each market to a shock from another market and these therefore show the extent and speed of 
interaction among the different markets across time. As stated earlier, these two techniques are conducted based on the generalized approach developed by Pesaran and Shin (1998), which overcomes the problem of variable-ordering sensitivity associated with the Cholesky decomposition method.

Finally, the ECM, which can be performed when the variables are cointegrated, makes it possible to trace the adjustment of markets from the short-term to the long-term. It allows the identification of causal relationships between the markets which otherwise cannot be detected (Lin and Swanson, 1993, pp. 615 and 617).

The study used daily Morgan Stanley Capital International (MSCI) price index data, expressed in US dollars, covering the period January 1, 1993 to September 10, 2001. The sample period is broken into two sub-periods to take into account the on-set of the Asian financial crisis of 1997. The first sub-period is from January 1, 1988 to July 1, 1997 while the second sub-period is from January 1, 1998 to September 10, 2001. The MSCI data are well known for their reliability and absence of double listing.

It should be noted that although the US equity market is not part of the group of markets being studied, it is included as one of the variables in the models used. It is well accepted and documented in the literature (see for instance, Eun and Shim, 1989 and Espitia and Santamaria, 1994) that the US stock market is the most influential equity market in the world. Even in the Asian markets, the US is more influential than Japan (Liu and Pan, 1997). Thus, not including 
the US in a study of capital market integration leads to spurious results (see Espitia and Santamaria, 1994, for further discussion of this issue).

\section{EMPIRICAL RESULTS}

\section{Preliminary testing}

The results of the cointegration analyses and innovation accounting for both sub-periods are presented and discussed in this section. Before undertaking the cointegration analyses, tests were conducted to ensure that the series are non-stationary and that the proper lag lengths are utilised in the vector autoregression (VAR). To determine the stationarity of the different time series, unit root tests based on the Augmented Dickey Fuller (Dickey and Fuller, 1981 and Said and Dickey, 1984) or ADF and Phillips-Perron (1988) or PP tests were performed. The results of these tests, based on the time-trend model indicate that all series, with the exception of Australia, are non-stationary (see Table 4$)^{1}$. Thus, the conduct of cointegration analyses was warranted. A likelihood ratio test was used to determine the optimum lag length. Essentially, this entailed testing first lags of 1 vs. $2\left(\mathrm{H}_{0}: \mathrm{k}=1 \mathrm{vs} . \mathrm{H}_{1}: \mathrm{k}=2\right)$ and if the null hypothesis is rejected, the test continues by testing the next higher lags. The results of this test indicate the optimum lag lengths, at the $10 \%$ level of confidence, to be 2 and 3, during the periods before and after the Asian crisis, respectively (see Table 5).

Insert Tables 4 and 5 here 


\section{Analyses of long-term relationship}

No cointegration was found between Australia and the Chinese states during the periods before and after the Asian crisis. The trace statistics are calculated to test the null hypothesis of $r=0$ (no cointegration), versus the alternative hypothesis of $r>0$ (cointegration) and the results are

presented in Table 6. The computed trace statistic corresponding to $r=0$ is 83.85 for the period before the crisis and 78.21 for the period after the crisis. Since the critical value of the trace statistic is 94.15 , the null hypothesis cannot be rejected. Thus, it can be concluded that no longterm stable relationship exists between the Australian and Chinese states equity markets.

\section{Insert Table 6 here}

\section{Analyses of short-term interactions}

In terms of the short-term, during the period before the Asian crisis, the only noticeable interaction of Australia with the Chinese states was with Hong Kong, as can be seen from the results of the forecast variance decomposition shown in Table 7. Australia accounted for $4.0 \%$ of Hong Kong’s forecast variance while Hong Kong was responsible for 5.4\% of Australia's forecast variance. In a sense, Hong Kong was more influential on Australia than Australia on Hong Kong

After the Asian crisis, Australia became more interactive with the other markets as is indicated by two items in Table 7. First, Australia's equity market became less affected by shocks coming 
from itself, as shown by the decrease in the percentage from $78.3 \%$ (pre-crisis) to $67.1 \%$ (postcrisis) and thus, it was now more affected by news originating from other markets. Second, the percentage of forecast variance of each of the Chinese states due to an Australian shock, shown in columns 2 and 4, and the percentage of Australian forecast variance due to innovations in each of the Chinese states, shown in columns 3 and 5, increased. The biggest increase in percentage occurred in the case of Singapore, which means that Australia, in the post crisis period, became significantly interdependent with this market in addition to Hong Kong. Although the forecast variance percentages for Taiwan and China also increased, these still remained relatively small. Thus, in the short term, Australia only had significant interactions with Hong Kong, during the period before the crisis, and with Hong Kong and Singapore, during the period after the crisis.

\section{Insert Table 7 here}

The structure of Australia's interaction with Hong Kong and Singapore is depicted by the results of the impulse response calculations presented in graphical form in Figures 1, 2 and 3. Figure 1 illustrates Australia's interaction with Hong Kong during the period before the crisis. Australia and Hong Kong react positively to a shock from each other immediately during day 1 and complete their interaction by day 2. Australia’s interaction with Hong Kong and Singapore, during the period after the crisis, is shown in Figures 2 and 3. It can be seen that the interaction is very much in the same way as that between Australia and Hong Kong during the period before the crisis. Thus, these findings support the hypothesis that the interaction between Australia and the Chinese states will occur within a period of two days. 
Insert Figures 1, 2 and 3 here

In summary, the results indicate that a short-term relationship exists between Australia, Hong Kong and Singapore, while no long-term relationship is found. Furthermore, a structural break, the Asian Crisis in this case, appears to alter the short-term relationships between markets, with Australia becoming a more open market following the crisis.

\section{CONCLUSION}

Systematic interactions between equity markets play a potentially important role in the asset allocation and risk minimisation strategies of investors. While there are many studies that have investigated market interactions, none have directly examined the relationship between the Australian equity market and those of the Chinese states. This paper investigates the extent and structure of price linkages between Australia and the Chinese states, both in the long and shortterm.

The study did not find any stable long-term relationship between the Australian and Chinese states equity markets. In the short-term, during the period before the Asian crisis, Australia only had noticeable interaction with Hong Kong. Australia and Hong Kong mutually influenced each other, although Hong Kong was more influential on Australia. After the Asian crisis, Australia became more interdependent with other markets, where in addition to Hong Kong, it was also significantly linked with Singapore. It continued not to have any significant interaction with the markets of China and Taiwan. 
In terms of the structure of the interaction, Australia reacts to a shock from Hong Kong and Singapore positively during the first day and mostly completes this reaction by day 2. Hong Kong and Singapore also react to an Australian shock in the same way.

These results imply that, in the long-term, all of the Chinese states equity markets offer good opportunities for international portfolio diversification for Australian investors, while in the short-term, only China and Taiwan do. From the Australian financial market regulators viewpoint, the significant short-term interactions between Australia, Hong Kong and Singapore indicate that the risk of contagion to Australia from these two markets may be a matter for consideration. 


\section{REFERENCES}

Allen, D.E. and Macdonald, G. 1995, “The Long-Run Gains from International Equity Diversification: Australian Evidence from Cointegration Tests”, Applied Financial Economics, vol. 5, pp. 33-42.

Cheung, Y.L. and Ho, Y.K. 1991, “The Intertemporal Stability of the Relationships Between the Asian Emerging Equity Markets and the Developed Equity Markets”, Journal of Business Finance and Accounting, vol. 18, pp. 235-254.

Dekker, A., Sen, K. and Young, M.R. 2001, “Equity Market Linkages in the Asia Pacific Region: A Comparison of the Orthogonalised and Generalised VAR Approaches”, Global Finance Journal, vol. 12, pp. 1-33.

Department of Foreign Affairs and Trade 2000, The APEC Region Trade and Investment, Department of Foreign Affairs and Trade, Canberra, Australia.

Dickey, D.A. and Fuller. W.A. 1981, “Likelihood Ratio Statistics for Autoregressive Time Series with a Unit Root”, Econometrica, vol. 49, pp. 1057-1072.

Dickinson, D.G. 2000, “Stock Market Integration and Macroeconomic Fundamentals: An Empirical Analysis, 1980-95”, Applied Financial Economics, vol. 10, pp. 261-276.

Emerging Stock Markets Factbook 2001. Standard \& Poor’s, New York.

Espitia, M. and Santamaria, R. 1994, “International Diversification Among the Capital Markets of the EEC”, Applied Financial Economics, vol. 4, pp. 1-10.

Eun, C.S. and Shim, S. 1989, “International Transmission of Stock Market Movements” Journal of Financial and Quantitative Analysis, vol. 24, pp. 241-256. 
Johansen, S. and Juselius, K. 1990, "Maximum Likelihood Estimation and Inference On Cointegration - With Applications To The Demand For Money”, Oxford Bulletin of Economics and Statistics, vol. 52, pp. 169-210.

Jorion, P. and Schwartz, E. 1986, “Integration vs. Segmentation in the Canadian Stock Market”, Journal of Finance, vol. 41, pp. 603-614.

Lin, A. and Swanson, P.E. 1993. “Measuring Global Money Market Interrelationships: An Investigation of Five Major World Currencies”, Journal of Banking and Finance, vol. 17, pp. 609-628.

Liu, Y.A. and Pan, M.S. 1997, "Mean and Volatility Spill-Over Effects in the U.S. and PacificBasin Stock Markets”, Multinational Finance Journal, vol. 1, pp. 47-62.

Masih, R. and Masih, A. 2001, "Long and Short Term Dynamic Causal Transmission amongst International Stock Markets”, Journal of International Money and Finance, vol. 20, pp. 563587.

McNelis, P.D. 1993, “The Response of Australian Stock, Foreign Exchange, and Bond Markets to Foreign Asset Returns and Volatilities”, Research Discussion Paper, Economic Research Department, Reserve Bank of Australia.

Pesaran, H. and Shin, Y. 1998. “Generalised Impulse Response Analysis In Linear Multivariate Models”, Economics Letters, vol. 58, pp. 17-29.

Phillips, P.C.B. and Perron, P. 1988, “Testing for a Unit Root In Time Series Regression”, Biometrika, vol. 75, pp. 335-346.

Roca, E. and Selvanathan, E.A. 2001, “Australia and the Three Little Dragons: Are Their Equity Markets Interdependent?”, Applied Economics Letters, vol. 8, pp. 203-207.

Roger, S. 2001, “The Asian Crisis Four Years Ago”, Finance and Development, March, pp. 1-2. 
Said, E.S. and Dickey, D.A. 1984, “Testing For Unit Roots in Autoregressive-Moving Average Models of Unknown Order”, Biometrika, vol. 71, pp. 599-607.

World Development Indicators (2001). The International Bank for Reconstruction and Development, Washington D.C. 


\section{FOOTNOTES}

${ }^{1}$ Note although the ADF test results show that the Australian series is non-stationary, the PP results do not. However, it is hard to believe that the Australian series is stationary since previous studies (see Sheng and Tu, 2000, for instance) have found it to be non-stationary. Furthermore, when the PP test was conducted using a model with a constant but no time trend, the results show that the Australian series is non-stationary. Hence, it is taken that this series is non-stationary. 